Published December 2018

EKONOMIKAWAN : Jurnal Ilmu Ekonomi dan Studi Pembangunan

ISSN : 1693-7600 (Print), ISSN : 2598-0157 (Online), http://jurnal.umsu.ac.Id/index.php/ekawan

\title{
Pengembangan Wilayah Perdesaan Berbasis Pada Potensi Sumber Daya Alam di Kabupaten Bondowoso
}

\author{
Herman Cahyo Diartho \\ Fakultas Ekonomi dan Bisnis, Universitas Jember \\ Jl. Kalimantan No.37, Krajan Timur, Sumbersari, Kabupaten Jember, Jawa Timur 68121 \\ e-mail : hermancahyodiaratho@yahoo.com
}

\begin{abstract}
ABSTRAK
Adanya kesenjangan antara daerah perkotaan dan pedesaan serta kemiskinan di pedesaan telah mendorong upaya-upaya pembangunan di daerah pedesaan. Salah satu upaya untuk melakukan modernisasi dan penguatan ekonomi perdesaan adalah dengan adanya dukungan penyediaan infrastruktur perdesaan yaitu jalan, air bersih, listrik dan prasarana kegiatan ekonomi lainnya. Dalam prakteknya, proses pembangunan perdesaan yang dilaksanakan selama ini belum berhasil mencapai tujuan tersebut, bahkan disisi lain telah menimbulkan berbagai permasalahan baru berupa kesenjangan antar kota dan desa. Hasil penelitian menunjukkan bahwa kawasan perdesaan di wilayah Kabupaten Bondowoso mempunyai beberapa klasifikasi perkembangan desa serta potensi sumber daya alamnya, yaitu : (Pertama). Kecamatan Tamanan dengan potensi ekonomi kreatif menghasilkan tiga hierarki, yaitu (a). Kelompok Hierarki I (Desa Tamanan, Desa Sukosari dan Desa Wonosuko), (b). Kelompok Hierarki II (Desa Karangmelok, Desa Kemirian, dan Desa Sumberkemuning) dan (c). Kelompok Hierarki III (Desa Mengen, Desa Sumberanom dan Desa Wonosuko), (Kedua). Kecamatan Wonosari dengan potensi agribis padi organik menghasilkan tiga hierarki, yaitu (a). Kelompok Hierarki I (Desa Wonosari, Desa Traktakan dan Desa Sumberkalong), (b). Kelompok Hierarki II (Desa Kapuran, Desa Pasarejo, Desa Tumeng, Desa Lombok Kulon dan Desa Lombok Wetan) dan (c). Kelompok Hierarki III (Desa Tangsil Wetan, Desa Jumpong, Desa Pelalangan dan Desa Bendoarum), (Ketiga). Kecamatan Sumberwringin dengan potensi agribis kopi rakyat menghasilkan tiga hierarki, yaitu (a). Kelompok Hierarki I (Desa Sumbergading), (b). Kelompok Hierarki II (Desa Sukorejo dan Desa Sukosarikidul) dan (c). Kelompok Hierarki III (Desa Tegaljati dan Desa Rejoagung) dan (Keempat). Kecamatan Binakal dengan potensi agroindustri tape dan ikan air tawar menghasilkan tiga hierarki, yaitu (a). Kelompok Hierarki I (Desa Sumbertengah dan Desa Bendelan), (b). Kelompok Hierarki II (Desa Jeruk Soksok, Desa Binakal dan Desa Baratan) dan (c). Kelompok Hierarki III (Desa Gadingsari, Desa Sumber Waru Desa Kembangan).
\end{abstract}

Kata Kunci : Pengembangan Wilayah Perdesaan, Potensi Sumber Daya Alam 


\title{
Development of Rural Areas Based on Potential Natural Resources in Bondowoso Regency
}

\begin{abstract}
The gap between urban and rural areas and poverty in rural areas has encouraged development efforts in rural areas. One of the efforts to modernize and strengthen the rural economy is to support the provision of rural infrastructure, namely roads, clean water, electricity and other economic infrastructure. In practice, the process of rural development which was implemented during this time have not managed to achieve that goal, even on the other hand have lead to various new problems in the form of the gap between cities and villages. The results of the research show that rural areas in the region Bondowoso District has several classifications of the development of the village as well as the potential of its natural resources, namely: (The First). Sub-district Tamanan with the potential of the creative economy produces three hierarchies, namely (a). The group Hierarchy I (the Village Tamanan, Sukosari and Wonosuko), (b). The group Hierarchy II (Village Karangmelok, Kemirian, and Sumberkemuning) and (c). The group Hierarchy III (the Village of Mengen, Sumberanom and Wonosuko), (The Second). Wonosari district with the potential of agrobusiness of organic rice produce three hierarchies, namely (a). The group Hierarchy I (Wonosari, Traktakan and Sumberkalong), (b). The group Hierarchy II (Kapuran, Pasarejo,Tumeng, Lombok Kulon, and Lombok Wetan) and (c). The group Hierarchy III (Village Tangsil Wetan, Jumpong, Pelalangan and Bendoarum), (The third). District Sumberwringin with the potential of agrobusiness of the coffee people produce three hierarchies, namely (a). The group Hierarchy I (Village Sumbergading), (b). The group Hierarchy II (Sukorejo and Sukosarikidul) and (c). The group Hierarchy III (Tegaljati and Desa Rejoagung) and (The Fourth). District Binakal with the potential of agro-tape and freshwater fish produce three hierarchies, namely (a). The group Hierarchy I (Sumbertengah and Bendelan), (b). The group Hierarchy II (the Village of Jeruk Soksok, Binakal and the Baratan) and (c). The group Hierarchy III (Gadingsari, Sumber Waru, Kembangan).
\end{abstract}

Key words : Development of Rural Areas and the Potential of Natural Resources 


\section{PENDAHULUAN}

Pembangunan desa akan semakin menantang dimasa depan dengan kondisi perekonomian daerah yang semakin terbuka dan kehidupan berpolitik yang lebih demokratis. Akan tetapi desa sampai kini, masih belum beranjak dari profil lama, yakni terbelakang dan miskin. Meskipun banyak pihak mengakui bahwa desa mempunyai peranan yang besar bagi kota, namun tetap saja desa masih dipandang rendah dalam hal ekonomi ataupun yang lainnya. Padahal kita ketahui bahwa sebagian besar penduduk Indonesia berdiam di daerah pedesaan dan berprofesi sebagai petani kecil (lahan terbatas atau sempit). Oleh karena itu, sudah sewajarnya bila pembangunan pedesaan harus menjadi prioritas utama dalam segenap rencana strategi dan kebijakan pembangunan di Indonesia. Jika tidak, maka jurang pemisah antara kota dan desan akan semakin tinggi terutama dalam hal perekonomian. (Bappenas, 2012).

Kesenjangan antara kawasan perkotaan dan pedesaan serta kemiskinan di pedesaan telah mendorong upaya-upaya pembangungan di kawasan pedesaan. Meskipun demikian, pendekatan pengembangan kawasan pedesaan seringkali dipisahkan dari kawasan perkotaan. Hal ini telah mengakibatkan terjadinya proses urban bias yaitu pengembangan kawasan pedesaan yang pada awalnya ditujukan untuk meningkatkan kawasan kesejahteraan masyarakat pedesaan malah berakibat sebaliknya yaitu tersedotnya potensi pedesaan ke perkotaan baik dari sisi sumberdaya manusia, alam, bahkan modal (Djakapermana, 2003:4).

Kebijakan pembangunan perdesaan selama ini disusun dengan tujuan untuk meningkatkan kesejahteraan masyarakat perdesaan dan mempercepat industrialisasi perdesaan. Sasaran utama yang ingin dicapai adalah meningkatnya pendapatan masyarakat perdesaan, terciptanya lapangan pekerjaan, tersedianya bahan pangan dan bahan lainya untuk konsumsi dan produksi, terwujudnya keselarasan hubungan ekonomi antara wilayah perdesaan dan wilayah perkotaan, menguatnya pertumbuhan ekonomi lokal, dan meningkatnya lembaga dan organisasi ekonomi masyarakat perdesaan. Dalam kaitan tersebut Pradhan (2003) menyatakan bahwa pembangunan perdesaan hanya dapat berkesinambungan apabila fasilitas prasarana dan sarana yang tersedia dapat menstimulasi serta mendorong aktivitas produksi dan pasar di wilayah perdesaan. Perdesaan sebagai pemasok hasil produksi pertanian dalam bentuk produk-produk primer harus didorong menjadi desa-desa yang mampu menghasilkan bahan olahan atau industri hasil pertanian sehingga menjadi kawasan pertumbuhan ekonomi lokal (Gamma Epsilon, 2014).

Penyusunan kebijakan pembangunan pedesaan secara umum dapat dilihat dalam tiga kelompok yaitu : (1) Kebijakan secara tidak langsung diarahkan pada penciptaan kondisi yang menjamin kelangsungan setiap upaya pembangunan pedesaan yang mendukung kegiatan sosial ekonomi, seperti penyediaan sarana dan prasarana pendukung (pasar, pendidikan, kesehatan, jalan, dan lain sebagainya), penguatan kelembagaan, dan perlindungan terhadap aktivitas sosial ekonomi masyarakat melalui undang- undang. (2) Kebijakan yang langsung diarahkan pada peningkatan kegiatan ekonomi masyarakat pedesaan. (3) Kebijakan khusus menjangkau masyarakat melalui upaya khusus, seperti penjaminan hukum melalui perundang-undangan dan penjaminan terhadapkeamanan dan kenyamanan masyarakat (Haeruman, 1997:11). 
Untuk mencapai tujuan pembangunan perdesaan diperlukan integrasi kegiatankegiatan pokok yang meliputi: (1) pembangunan sarana dan prasarana, (2). pembangunan sistem agribisnis, (3) pengembangan industri kecil dan rumah tangga,(4) penguatan lembaga dan organisasi ekonomi masyarakat, (5) pengembangan jaringan produksi dan pemasaran, (6) penguasaan teknologi tepat guna, (7) pengelolaan dan pemanfaatan sumber daya alam yang berkelanjutan dan peningkatan kehidupan sosial ekonomi kelompok keluarga miskin secara terpadu, (8) menyempurnakan struktur organisasi pemerintah desa dan lembaga-lembagaekonomi lainnya (Pranoto, 2002).

Menurut Kurnia (1999), upaya untuk melakukan modernisasi dan penguatan ekonomi perdesaan adalah melalui dukungan penyediaan infrastruktur perdesaan seperti jalan, listrik, air bersih dan prasarana kegiatan ekonomi lainnya. Dalam prakteknya, proses pembangunan perdesaan yang dilaksanakan selama ini belum berhasil mencapai tujuan tersebut, bahkan disisi lain telah menimbulkan berbagai permasalahan baru berupa kesenjangan antar kota dan desa, yaitu perbedaan tingkat kesejahteraan yang menyolok antara wilayah perdesaan dan perkotaan. Haltersebut selaras dengan pernyataan Mubyarto (2004), bahwa kesenjangan antara sektor industri dengan sektor pertanian itu tampak pada kesenjangan kota - desa.

Pembangunan industri, yang sebagian besar terletak di perkotaan, tumbuh pesat selama hampir 30 tahun. Sebaliknya, pembangunan sektor pertanian dan industri olahannya, yang hampir seluruhnya berada di daerah perdesaan, sangat lambat pertumbuhannya. Sektor pertanian merupakan suatu sistem yang menyeluruh dimana terkait dengan produsen dan konsumen. Sistem ini terkait dengan sub sistem proses penyimpanan, pengolahan hasil, produksi dan pemasaran (CIDA, 2003). Sebagai akibat kesenjangan wilayah kota-desa, hubungan interaksi antara keduanya tidak saling memperkuat, tetapi justru saling memperlemah. Dengan demikian, kebijakan pembangunan perdesaan selama ini belum mampu memberikan perubahan yang signifikan terhadap peningkatan kesejahteraan masyarakat, sehingga pendekatan kebijakan pembangunan selama ini perlu dipikirkan kembali. Berkembangnya kawasan kota sebagai pusat-pusat pertumbuhan ternyata tidak memberikan efek penetesan ke bawah (trickle down effect), tetapi justru menimbulkan efek pengurasan (back wash effect) sumberdaya dari wilayah perdesaan ke wilayah perkotaan, serta efek urbanisasi secara cepat.

Zeng dan Sui (2011) menyatakan bahwa hal tersebut merupakan fenomena yang umum terjadi diberbagai negara yang sedang berkembang di dunia. Pembangunan perdesaan melalui pengembangan berbasis agribisnis diharapkan dapat memberikan solusi yang tepat untuk mengatasi dan menjawab berbagai permasalahan tersebut. Pernyataan ini sejalan dengan konsep yang dikembangkan oleh Friedman dan Douglas (1975). Bahkan keduanya menekankan pentingnya pendekatan berbasis agribisnis dalam pengembangan pedesaan di kawasan Asia dan Afrika.

Kabupaten Bondowoso merupakan salah satu kabupaten yang mengembangkan konseppembangunan perdesaan yang berbasis pada potensi desa sebagai salah satu pendekatan dalam memacu pembangunan dan pengembanganwilayah desa.Dilihat dari potensi sumber dayaalam dan wilayah, Kabupaten Bondowoso memiliki potensi yang layak dikembangkan bidang pertanian,perikanan dan peternakan. Dalam upaya mempercepat pertumbuhan dan pengembangan wilayah perdesaan maka pemerintah Daerah Kabupaten Bondowoso mempunyai perencanaan strategis untuk memacu perkembangan wilayah perdesaan melalui sasaran utama yang meliput: 


\section{Published December 2018}

\section{EKONOMIKAWAN : Jurnal IImu Ekonomi dan Studi Pembangunan}

ISSN : 1693-7600 (Print), ISSN : 2598-0157 (Online), http://jurnal.umsu.ac.Id/index.php/ekawan

(1). Pengembangan pertanian yang berbasis potensi wilayah, dan (2). Pengembangan ekonomi kerakyatan dengan sasaran kawasan pedesaan melalui sektor agribisnis yang berkelanjutan.

Kawasan perdesaan di Kabupaten Bondowoso pada dasarnya memiliki potensi pertanian untuk dikembangkan dan berbagai inovasi yang telah dilakukan berhubungan erat dengan faktor internal dan eksternal yang dimiliki oleh desa. Faktor internal yang dimaksud terdiri dari kekuatan dan kelemahan yang dimiliki oleh desa sedangkan faktor eksternal berhubungan dengan peluang dan ancaman. Berdasarkan faktor internal dan eksternal serta potensi yang dimiliki maka dilakukan penelitian tentang : (a). Bagaimanakah keragaan relatif tingkat perkembangan desa dan (b). Bagaimanakah potensi sumber daya alam dan strategi untuk menuju kemandirian ekonomi desa di Kabupaten Bondowoso.

\section{KAJIAN TEORI}

Pendekatan yang diterapkan dalam pengembangan wilayah di Indonesia sangat beragam karena dipengaruhi oleh perkembangan teori dan model pengembangan wilayah serta tatanan sosial-ekonomi, sistem pemerintahan dan administrasi pembangunan. Pendekatan yang mengutamakan pertumbuhan tanpa memberikan perhatian pada pemerataan menyebabkan dampak negatif terhadap lingkungan, bahkan menghambat pertumbuhan itu sendiri (Direktorat Jenderal Penataan Ruang, 2013). Pengembangan wilayah dengan memperhatikan potensi pertumbuhan akan membantu meningkatkan pertumbuhan ekonomi berkelanjutan melalui penyebaran penduduk lebih rasional, meningkatkan kesempatan kerja dan produktivitas (Mercado, 2012).

Menurut Akil (2003), pendekatan yang mengutamakan pertumbuhan tanpa memberikan perhatian pada pemerataan menyebabkan dampak negatif terhadap lingkungan, bahkan menghambat pembangunan itu sendiri. Dalam kontek ini mulai dirasakan perlunya pendekatan yang meninjau kota-desa kawasan produksi serta prasarana pendukungnya sebagai satu kesatuan wilayah. Dalam hubungan ini, kegiatan ekonomi kota dan desa (sub urban) adalah saling tergantung (interdependent) dalam kontek perubahan penduduk jangka panjang dan tenaga kerja (Voith, 1998). Kasikoen (2005) menyatakan bahwa ada keterkaitan pembangunan perkotaan dan perdesaan dimana keterkaitan ini diekspresikan dalam bentuk fisik, sosial, ekonomi, politik dan idiologi yang sekaligus untuk mengatasi adanya ketidakseimbangan pembangunan di perkotaan dan perdesaan.

Kesenjangan pelaksanaan program pembangunan didalam mencapai tujuannya, bukanlah semata-mata kegagalan dalam penyelenggaraannya namun lebih kepada kebijakan yang diterapkan. Pada beberapa dekade yang lalu, cara pandang pembangunan lebih berorientasi pada laju pertumbuhan ekonomi dengan basis peningkatan investasi dan teknologi yang menimbulkan krisis yang sampai saat ini masih dirasakan. Penekanan pembangunan yang hanya pada pertumbuhan ekonomi yang menimbulkan masalah disampaikan juga oleh Djajadiningrat (1997). Titik berat pembangunan semata-mata pada pertumbuhan ekonomi dapat menyebabkan kerusakan lingkungan alam yang tidak dapat diperbaiki. Lingkungan alam juga merupakan unsur penting dari pertumbuhan ekonomi, dan apabila lingkungan alam turun melebihi daya dukungnya, maka ekonomi akan kehilangan daya untuk tumbuh. 


\section{Published December 2018}

EKONOMIKAWAN : Jurnal IImu Ekonomi dan Studi Pembangunan

ISSN : 1693-7600 (Print), ISSN : 2598-0157 (Online), http://jurnal.umsu.ac.id/index.php/ekawan

Menurut Shukla (2010), melalui perencanaan wilayah (regional planning) dapat mencapai kedua-duanya yaitu pembangunan dan keberlanjutan, jawaban ini dapat diuraikan sebagai berikut : (a). Perencanaan wilayah akan membantu pemanfaatan sumberdaya lokal yang ada, sumber daya fisik serta teknologi, (b). Perencanaan wilayah akan membantu pembuatan perencanaan dimana akan mengisi kebutuhan lokaldan (c). Perencanaan wilayah membantu mengurangi pembangunan yang kurang berimbang antar dan dalam wilayah.Sejalan dengan pernyataan di atas, menurut Erwidodo (1999), kesenjangan pertumbuhan antara wilayah perkotaan dan perdesaan telah memunculkan permasalahan kompleks antara lain meningkatnya arus migrasi penduduk desa ke kota, meningkatnya kemiskinan masyarakat dan "pengurasan" sumber daya alam. Ada beberapa hal yang menjadi penyebab terjadinya "pengurasan" tersebut, diantaranya yaitu : (1). Terbukanya akses ke daerah perdesaan seringkali mendorong kaum elit kota, pejabat pemerintah pusat, dan perusahaan-perusahaan besar untuk mengeksploitasi sumberdaya yang terdapat di desa. Masyarakat desa sendiri tidak berdaya karena secara politik dan ekonomi para pelaku eksploitasi sumberdaya tersebut memiliki posisi tawar yang jauh lebih kuat dan (2). Kawasan perdesaan sendiri umumnya dihuni oleh masyarakat yang kualitas SDM-nya kurang berkembang. Kondisi ini mengakibatkan ide-ide dan pemikiran modern dari kaum elit kota sulit untuk didesiminasikan. Oleh karena itu sebagian besar aktivitas pada akhirnya lebih bersifat enclave dengan mendatangkan banyak SDM dari luar yang dianggap lebih mempunyai keterampilan dan kemampuan.

Menurut Basri (1999), bahwa rendahnya tingkat sosial ekonomi masyarakat perdesaan dipengaruhi oleh: (1). Kondisi sosial ekonomi rumah tangga masyarakat yang mempengaruhi kapasitas individu, keluarga, dan kelompok masyarakat dalam melakukan interaksi sosial dan proses produksi; (2). Struktur kegiatan ekonomi sektoral yang menjadi dasar lapangan usaha dan pendapatan rumah tangga atau masyarakat; (3). Potensi daya dukung regional (geographical setting) seperti kondisi geografis, sumberdaya alam serta infrastruktur yang mempengaruhi pola kegiatan produksi dan distribusi; dan (4). Kelembagaan sosial ekonomi masyarakat yang mendukung interaksi sosial dan jaringan kerja produksi dan pemasaran pada skala lokal, regional dan global.Dengan kata lain, masalah utama dalam pembangunan wilayah perdesaan adalah kebijakan yang kurang berfihak terhadap masyarakat perdesaan danrendahnya kemampuan sumber daya manusia dalam mengelola sumber-sumber daya alam guna pembangunan masyarakat perdesaan.

Miyoshi (1997) mengemukakan pendapat Friedman dan Douglas, bahwa strategi pembangunan perdesaan yang cocok adalah supaya memperhatikan hal-hal sebagai berikut yaitu: (1) sektor pertanian harus dipandang sebagai leading sektor; (2) kesenjangan pendapatan dan kondisi kehidupan antara kota dan desa harus dikurangi; (3) small scale production untuk pemasaran lokal harus dilindungi melawan kompetisi dari pengusaha besar. Menurut Dutta (2002), pembangunan rural small enterprise sangat penting untuk mengembangkan pusat-pusat pertumbuhan atau kota kecil yang berperan sebagai pusat pemasaran desa-desa di sekitarnya. Akibat dari kegagalan pembangunan yang disebabkan oleh terjadinya urban bias diatas, pembangunan di wilayah perdesaan mengalami kekurangan investasi modal, dampaknya telah menimbulkan kehilangan kesempatan kerja bagi masyarakat perdesaan. 
Dalam kondisi seperti ini posisi tawar masyarakat perdesaan menjadi semakin lemah sehingga pengambilan keputusan pembangunan menjadi tersentralisasi di kota-kota tanpa menghiraukan kondisi perdesaan. Pembangunan di perdesaan semakin terpuruk sedangkan pertumbuhan ekonomi kota-kota relatif semakin besar yang diikuti dengan eksploitasi sumberdaya di wilayah perdesaan. Keadaan ini mendorong terjadinya kerusakan-kerusakan sumberdaya alam dan lingkungan hidup yang pada gilirannya berpengaruh terhadap kesejahteraan masyarakat luas, baik di wilayah perdesaan maupun di kawasan perkotaan sendiri.

Kondisi diatas terjadi antara lain karena investasi-investasi di wilayah perdesaan baik secara fisik (material capital: man-made and natural), sumberdaya manusia (human capital) dan sumberdaya sosial (social capital) dan kebijaksanaan pengembangan teknologi tidak dilakukan secara tepat dan memadai, bahkan di masa yang lalu terkesan banyak diabaikanDengan semakin meluasnya masalah-masalah sejenis di sebagian besar negara-negara berkembang, para pakar pembangunan mulai berpikir untuk mencari solusi bagi pembangunan daerah perdesaan. Pembangunan yang berimbang secara spasial menjadi penting karena dalam skala makro hal ini menjadi prasyarat bagi tumbuhnya perekonomian nasional yang lebih efisien, berkeadilan dan berkelanjutan.

Untuk itu menurut Rustiadi (2003), pengembangan wilayah harus mengandung prinsip-prinsip: (1) mengedepankan peran serta masyarakat dan memprioritaskan untuk mejawab kebutuhan masyarakat. Pemerintah lebih berperan sebagai fasilitator pembangunan dari pada sebagai pelaksana. (2) Menekankan aspek proses dibandingkan pendekatan-pendekatan yang menghasilkan produk-produk perencanaan berupa master plan dan sejenisnya. Berdasarkan Undang-Undang Nomor 24 Tahun 1992, tentang Penataan Ruang, bahwa proses perencanaan tata ruang, pemanfaatan ruang dan pengendalian ruang yang merupakan suatu sistem yang terkait satu sama lainnya. Rencana Tata Ruang sebagai acuan dalam pembangunan daerah pada era otonomi ini perlu dilaksanakan dengan pendekatan pengembangan wilayah bukan lagi pendekatan sektor sebagaimana dilakukan pada masa lalu.

Menurut Hul (1998), perencanaan tata ruang merupakan suatu mekanisme integratif untuk mengkoordinasikan berbagai strategis pembangunan. Pendekatan pengembangan wilayah harus dilakukan dengan penetapan struktur ruang dan pola pemanfaatan ruang yang disusun berdasarkan karakteristik, potensi, kebutuhan daerah, kepentingan stakeholders, daya dukung daerah serta mempertimbangkan perkembangan dinamika pasar dan dampak arus globalisasi. Lebih lanjut, Rondinelli (1985), ada tiga konsep dalam pengembangan wilayah yaitu: (1) kutub-kutub pertumbuhan (growth pole); (2) integrasi fungsi (functional integration), dan (3) pendekatan pendesentralisasian wilayah (decentralized territorial approaches). Selanjutnya Chen dan Salih (1978), mengemukakan bahwa mengadopsi pendekatan kutub-kutub pertumbuhan (growth pole approach) oleh negara-negara ketiga merefleksikan dua bentuk pemikiran yang bijaksana yaitu: pertama, industrialisasi dengan teknologi modern dapat di desentralisasikan manfaatkannya pada daerah perdesaan, kedua, keterpaduan pada tingkat nasional melalui strategi kutub-kutub pertumbuhan dapat memecahkan masalah pembangunan regional. Pendekatan pembangunan agropolitan merupakan bagian dari pada pengembangan wilayah skala kawasan merupakan senergitas pembangunan antara kota-desa (urban rural development). 
Untuk mewujudkan kemandirian pembangunan perdesaan yang didasarkan pada potensi wilayah desa itu sendiri, dimana keterkaitan dengan perekonomian kota harus bisa diminimalkan, maka pendekatan agropolitan dapat menjadi salah satu pendekatan pembangunan perdesaan. Sebagai aktivitas pembangunan yang terkonsentrasi di wilayah perdesaan dengan jumlah penduduk antara 50.000 sampai 150.000 orang, agropolitan menjadi relevan dengan wilayah perdesaan karena pada umumnya sektor pertanian dan pengeIolaan sumberdaya alam memang merupakan mata pencaharian utama dari sebagian besar masyarakat perdesaan, Lembaga Pendidikan Ekonomi dan Masyarakat (1996).

\section{METODE}

Analisis skalogram digunakan untuk mengetahui keragaan relatif tingkat perkembangan desa di Kabupaten Bondowoso. Dengan Analisis skalogram ini dapat ditentukan peringkat pemukiman atau wilayah dan kelembagaan atau fasilitas pelayanan. Asumsi yang digunakan adalah bahwa wilayah yang memiliki peringkat tertinggi adalah lokasi yang dapat menjadi pusat pelayanan. Berdasarkan analisis ini dapat ditentukan prioritas pengadaan sarana dan prasarana disetiap unit wilayah yang dianalisis.

Menurut Priyanto (2010) bentuk lain yang merupakan modifikasi dari metode skalogram adalah dengan penentuan Indeks Perkembangan Desa (IPD). Model analisis inilah yang digunakan dalam penelitian ini. Penghitungan IPD dilakukan dengan melakukan faktor koreksi untuk setiap data yang digunakan. Faktor koreksi adalah luas wilayah, jumlah penduduk, jumlah rumah tangga atau dilakukan invers pada variabel tertentu. Analisis skalogram ini didasarkan pada fasilitas yang dimiliki desa. Kemudian dilakukan standarisasi dengan nilai minimum dan nilai standar deviasinya. Model untuk menentukan IPD suatu wilayah atau pusat pelayanan adalah :

$$
\begin{aligned}
& \mathrm{IPD}_{\mathrm{j}}=\sum_{i}^{n} I_{i j}^{\prime}, \\
& \text { Dimana: } \quad \mathrm{I}_{\mathrm{ij}}^{\prime}=\frac{{ }_{i j}-I_{i \min }}{S D_{i}}
\end{aligned}
$$

Keterangan:

IPDj = Indeks Perkembangan Desa ke-j

I'ij = Nilai indikator perkembangan ke-i terkoreksi/terstandarisasi desa ke-j

Iij = Nilai indikator perkembangan ke-i desa ke-j

Ii min = Nilai indikator perkembangan ke-i terkecil

$\mathrm{SDi}=$ Standar Deviasi indikator perkembangan ke-i

\section{HASIL DAN PEMBAHASAN}

Hasil analisis terhadap variabel keragaan perkembangan perdesaan salah satunya menghasilkan skor setiap desa. Tujuan dari analisis kelompok ini adalah untuk membuat pengelompokan (clustering) perkembangan desa di Kabupaten Bondowoso serta mempelajari karakteristik masing-masing kelompok perdesaan. Data perkembangan kawasan perdesaan di Kabupaten Bondowoso secara spasial g terbagi menjadi 3 (tiga) kelompok. 
Pola penyebaran perkembangan perdesaan untuk kelompok I dan II memiliki tingkat perkembangan maju dan sedang pada umumnya berada di tengah kawasan pusat administrasi kecamatan yang merupakan kawasan yang mempunyai aksesbilitas yang lebih baik di Kabupaten Bondowoso. Sehingga mempermudah masyarakat perdesaan dalam melakukan aktifitas menuju ke pusat-pusat pelayanan publik dan kegiatan ekonomi.

Bentuk perencanaan pembangunan perdesaaan yang berbasis pada potensi wilayah juga menjadi arah dan tujuan dalam pembangunan perdesaan di Kabupaten Bondowoso. Penerapan bentuk perencanaan pembangunan perdesaan dilakukan di wilayah Kabupaten Bondowoso dilakukan berbasis wilayah. Kluster wilayah terhadap pembangunan kawasan perdesaan berbasis potensi wilayah sebagai berikut : (1). Kluster Wilayah Perdesaan Berbasis Ekonomi Kreatif, (2). Kluster Wilayah Perdesaan Berbasis Agribisnis dan (3). Kluster Wilayah Perdesaan Berbasis Agroindustri.

\section{Wilayah Perdesaan Berbasis Potensi Ekonomi Kreatif Batik di Kecamatan Tamanan.}

Hasil analisis terhadap variabel keragaan perkembangan perdesaan salah satunya menghasilkan skor setiap desa. Tujuan dari analisis kelompok ini adalah untuk membuat pengelompokan (clustering) perkembangan desa di Kecamatan Tamanan Kabupaten Bondowoso yang mempunyai basis potensi wilayah ekonomi kreatif berbentuk Batik Tamanan. Data perkembangan kawasan perdesaan di Kecamatan Tamanan Kabupaten Bondowoso terbagi menjadi 3 (tiga) kelompok yang dijelaskan pada tabel dibawah.

Tabel 1

Kategori Perkembangan Desa di Kecamatan Tamanan

\begin{tabular}{|c|l|c|}
\hline No & \multicolumn{1}{|c|}{ Nama Desa } & Kategori Perkembangan Desa \\
\hline 1 & Tamanan, Sukosari, Wonosuko & Kelompok Hirarkhi ke I \\
\hline 2 & Karangmelok, Kemirian dan Sumber kemuning & Kelompok Hirarkhi ke II \\
\hline 3 & Mengen, Sumberanom dan Wonosuko & Kelompok Hirarkhi ke III \\
\hline
\end{tabular}

Perkembangan perdesaan yang termasuk kelompok I dan II memiliki tingkat perkembangan maju dan sedang pada umumnya berada di tengah kawasan pusat administrasi kecamatan yang merupakan kawasan yang mempunyai aksesbilitas yang lebih baik di Kabupaten Bondowoso. Adapun kawasan perdesaan yang masuk pada keolompok keragaan III adalah desa yang memiliki tingkat perkembangan rendah.Perkembangan kawasan desa di wilayah Kecamatan Tamanan Kabupaten Bondowoso akan lebih jelas apabila diilustrasikan dengan gambar berikut ini. 


\section{Published December 2018}

\section{EKONOMIKAWAN : Jurnal Ilmu Ekonomi dan Studi Pembangunan}

ISSN : 1693-7600 (Print), ISSN : 2598-0157 (Online), http://jurnal.umsu.ac.id/index.php/ekawan

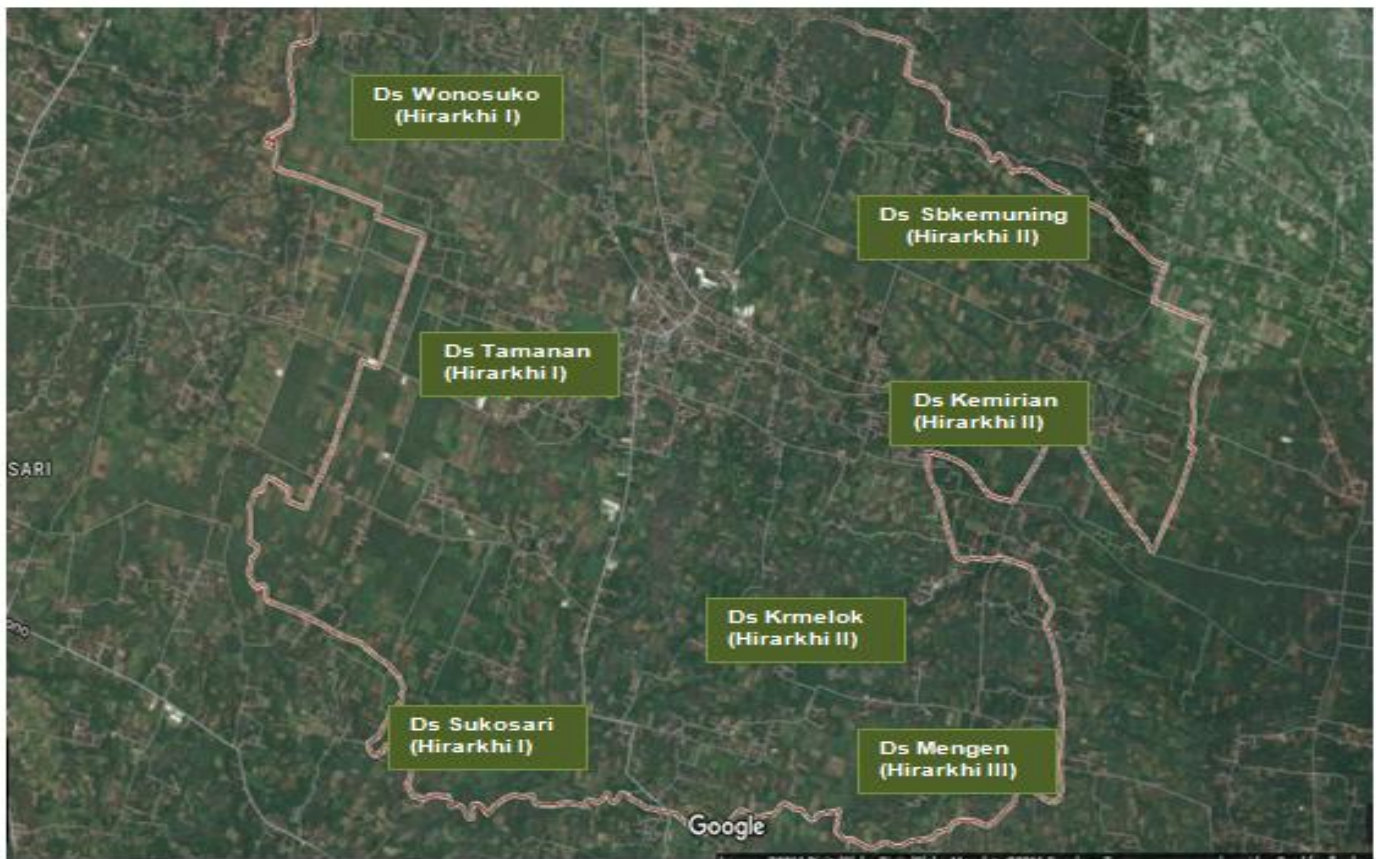

Gambar 1

Penyebaran Perkembangan Desa di Kecamatan Tamanan

Berdasarkan peta penyebaran perkembangan kawasan perdesaan di Kecamatan Tamanan terlihat adanya pola penyebaran. Kawasan perdesaan yang termasuk dalam kategori perkembangan kurang maju (hierarki III) umumnya berada di ujung selatan Kabupaten Bondowoso. Penyebaran kawasan perdesaan yang termasuk hierarki II tidak menunjukkan pola yang jelas, dengan kata lain beberapa desa di Kecamatan Tamanan Kabupaten Bondowoso menyebar secara spasial di semua wilayah di Kecamatan Tamanan. Selanjutnya terdapat tiga kawasan perdesaan yang termasuk dalam kategori perkembangan maju (hierarki I) yaitu Desa Wonosuko, Tamanan dan Desa Sukosari.

Pola pendekatan kebijakan yang bersifat spesifik merupakan strategi yang dapat mendorong terwujudnya perencanaan pembangunan perdesaaan yang berbasis pada potensi wilayah dengan memperhatikan faktor derajat kelompok perkembangan perdesaan. Pada tabel dibawah menjelaskan karakteristrik masing-masing derajat keragaaan perkembangan wilayah perdesaan di Kecamatan Tamanan Kabupaten Bondowoso serta arah pengembangan strategis dan terpadu terhadap perdesaan yang berbasis pada potensi wilayah. 


\section{Published December 2018}

EKONOMIKAWAN : Jurnal Ilmu Ekonomi dan Studi Pembangunan

ISSN : 1693-7600 (Print), ISSN : 2598-0157 (Online), http://jurnal.umsu.ac.id/index.php/ekawan

Tabel 2

Formulasi Strategi terhadap Pengembangan Kawasan Perdesaan

di Kecamatan Tamanan di Kabupaten Bondowoso

\begin{tabular}{|c|c|c|}
\hline $\begin{array}{c}\text { Derajat } \\
\text { Keragaan } \\
\text { Perdesaan }\end{array}$ & $\begin{array}{c}\text { Karakteristik Kawasan } \\
\text { Perdesaan }\end{array}$ & $\begin{array}{l}\text { Strategi Pengembangan Kawasan } \\
\text { Perdesaan di Kecamatan Tamanan }\end{array}$ \\
\hline $\begin{array}{c}\text { Wilayah } \\
\text { perdesaan } \\
\text { dengan tingkat } \\
\text { perkembangan } \\
\text { baik } \\
\text { (Hierarkhi I) }\end{array}$ & $\begin{array}{l}\text { Tingkat kesejahteraan } \\
\text { penduduk tinggi. Akses } \\
\text { informasi dan komunikasi } \\
\text { baik dan mendukung, } \\
\text { aksesbilitas terhadap pusat } \\
\text { pemerintahan kecamatan } \\
\text { baik, tingkat kesejahteraan } \\
\text { penduduk sedang dan } \\
\text { merata, sarana pendidikan } \\
\text { dan kesehatan yang } \\
\text { memadai, sarana ekonomi } \\
\text { cukup memadai, kualitas } \\
\text { lingkungan baik, tingkat } \\
\text { partisipasi warga sedang }\end{array}$ & $\begin{array}{l}\text { 1. Meningkatan jumlah dan jenis } \\
\text { usaha rumah tangga dan industri } \\
\text { kecil/mikro batik } \\
\text { 2. Meningkatkan jumlah dan akses } \\
\text { pada sarana pendidikan dan } \\
\text { kesehatan. } \\
\text { 3. Meningkatkan kualitas SDM salah } \\
\text { satunya melalui peningkatan akses } \\
\text { terhadap sarana teknologi informasi } \\
\text { dan lembaga kursus/keterampilan } \\
\text { serta meningkatkan peran serta aktif } \\
\text { warga masyarakat melalui lembaga- } \\
\text { lembaga non profit }\end{array}$ \\
\hline $\begin{array}{c}\text { Wilayah } \\
\text { perdesaan } \\
\text { dengan tingkat } \\
\text { perkembangan } \\
\text { sedang } \\
\text { (Hierarkhi II) }\end{array}$ & $\begin{array}{l}\text { Tingkat kesejahteraan } \\
\text { penduduk tinggi, Akses } \\
\text { informasi dan komunikasi } \\
\text { baik dan mendukung, akses } \\
\text { terhadap pusat pemerintahan } \\
\text { kecamatan cukup baik, } \\
\text { jumlah dan akses sarana } \\
\text { pendidikan dan kesehatan } \\
\text { yang memadai, sarana } \\
\text { ekonomi memadai, kualitas } \\
\text { lingkungan baik, partisipasi } \\
\text { warga tinggi }\end{array}$ & 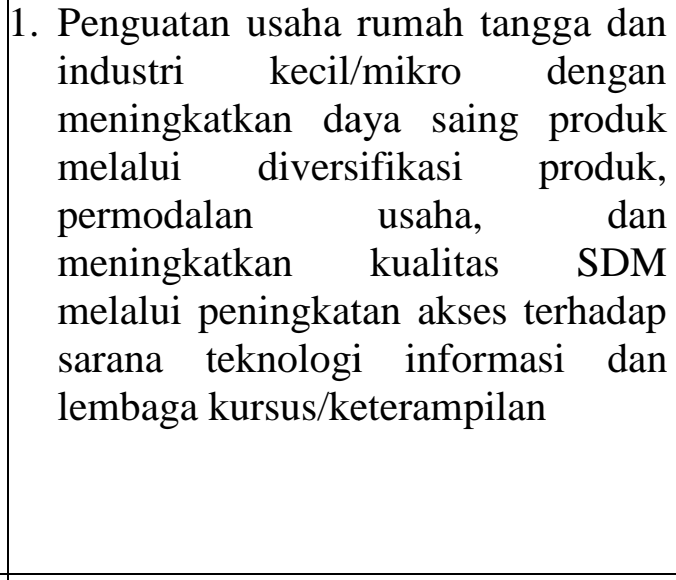 \\
\hline $\begin{array}{c}\text { Wilayah } \\
\text { perdesaan } \\
\text { dengan tingkat } \\
\text { perkembangan } \\
\text { kurang } \\
\text { (Hierarkhi III) }\end{array}$ & $\begin{array}{l}\text { Tingkat kesejahteraan } \\
\text { penduduk rendah, akses } \\
\text { terhadap pusat pemerintahan } \\
\text { kecamatan rendah, sarana } \\
\text { ekonomi terbatas, kualitas } \\
\text { lingkungan rendah, } \\
\text { partisipasi warga rendah }\end{array}$ & $\begin{array}{l}\text { 1. Meningkatkan taraf hidup } \\
\text { masyarakat, dengan terus membuka } \\
\text { kesempatan kerja melalui } \\
\text { pengembangan jumlah dan jenis } \\
\text { usaha rumahtangga dan industri } \\
\text { kecil/mikro, pemberian modal usaha } \\
\text { maupun pendampingan, sehingga } \\
\text { pembentukan koperasi menjadi hal } \\
\text { yang sangat penting untuk } \\
\text { diwujudkan. }\end{array}$ \\
\hline
\end{tabular}




\section{Published December 2018}

\section{EKONOMIKAWAN : Jurnal Ilmu Ekonomi dan Studi Pembangunan}

ISSN : 1693-7600 (Print), ISSN : 2598-0157 (Online), http://jurnal.umsu.ac.id/index.php/ekawan

\section{Wilayah Perdesaan Berbasis Potensi Agribis Padi Organik di Kecamatan Wonosari}

Hasil analisis terhadap variabel keragaan perkembangan perdesaan salah satunya menghasilkan skor setiap desa. Tujuan dari analisis kelompok ini adalah untuk membuat pengelompokan (clustering) perkembangan desa di Kecamatan Wonosari Kabupaten Bondowoso yang mempunyai basis potensi wilayah ekonomi agribis padi organik. Data perkembangan kawasan perdesaan di Kecamatan Wonosari Kabupaten Bondowoso terbagi menjadi 3 (tiga) kelompok yang dijelaskan pada tabel dibawah.

Tabel 3

Kategori Perkembangan Desa di Kecamatan Wonosari

\begin{tabular}{|c|l|c|}
\hline No & \multicolumn{1}{|c|}{ Nama Desa } & Kategori Perkembangan Desa \\
\hline 1 & Wonosari, Traktakan, Sumberkalong & Kelompok Hirarkhi ke I \\
\hline 2 & $\begin{array}{l}\text { Kapuran, Pasarejo, Tumpeng, Lombok Kulon } \\
\text { dan Lombok Wetan }\end{array}$ & Kelompok Hirarkhi ke II \\
\hline 3 & $\begin{array}{l}\text { Tangsil Wetan, Jumpong, Pelalangan dan } \\
\text { Bendoarum }\end{array}$ & Kelompok Hirarkhi ke III \\
\hline
\end{tabular}

Perkembangan kawasan desa di wilayah Kecamatan Wonosari Kabupaten Bondowoso akan lebih jelas apabila diilustrasikan dengan gambar dibawah ini.

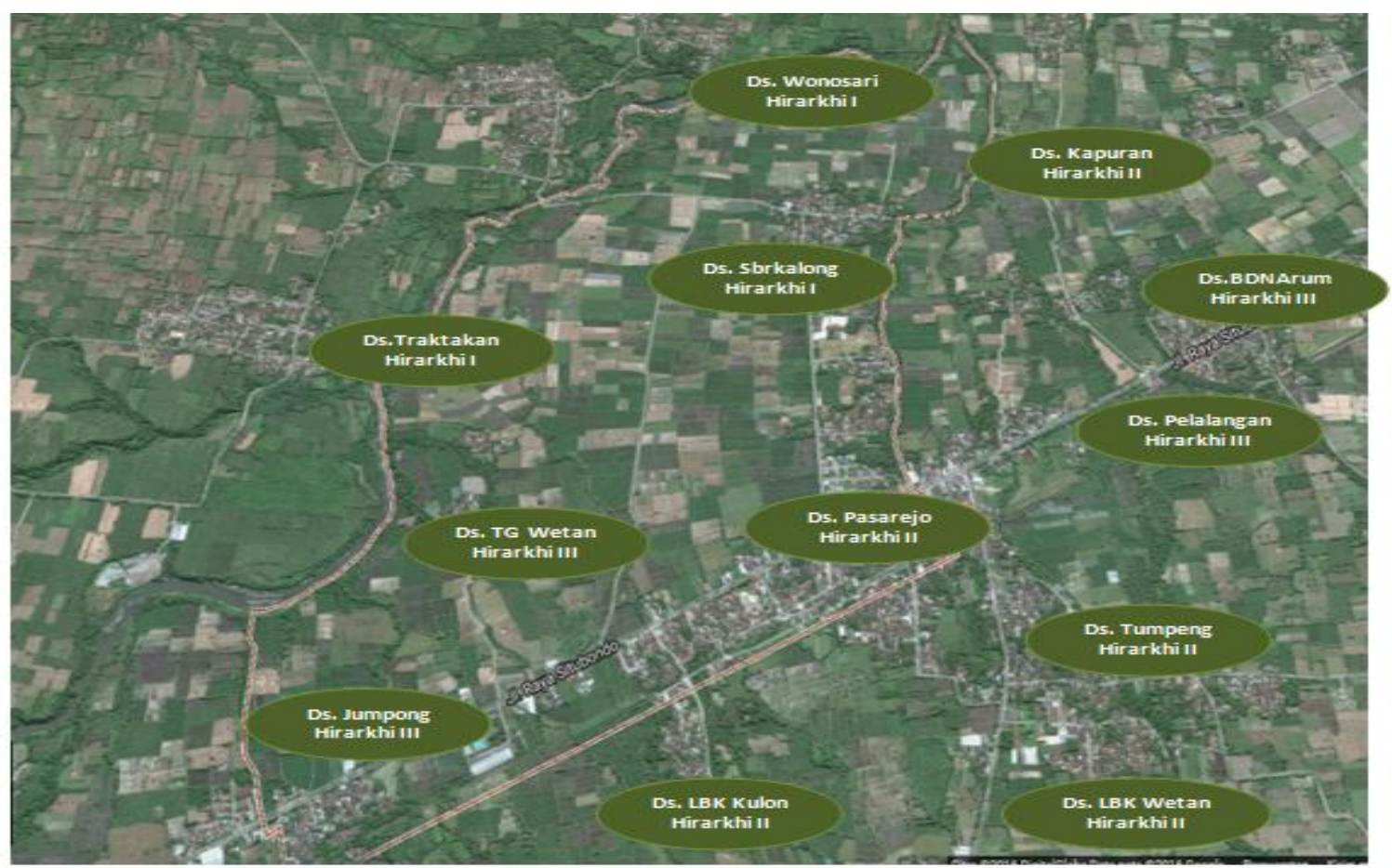

Gambar 2

Penyebaran Perkembangan Desa di Kecamatan Wonosari 


\section{Published December 2018}

\section{EKONOMIKAWAN : Jurnal Ilmu Ekonomi dan Studi Pembangunan}

ISSN : $1693-7600$ (Print), ISSN : 2598-0157 (Online), http://jurnal.umsu.ac.id/index.php/ekawan

Berdasarkan peta penyebaran perkembangan kawasan perdesaan di Kecamatan Wonosari terlihat adanya pola penyebaran. Pola sebaran terhadap keragaan perkembangan kawasan perdesaan yang berbeda-beda di wilayah Kecamatan Wonosari Kabupaten Bondowoso memerlukan metode pendekatan yang ragam dalam mendorong perkembangan wilayah perdesaan berbasis potensi wilayah sebagai dasar perencanaan pengembangan kawaasan perdesaan berbasis pada potensi. Oleh karena itu harus dikembangkan formulasi strategi yang bersifat spesifik sesuai dengan keragaan kelompok perkembangan desa masing-masing untuk mewujudkan pertumbuhan yang berimbang dan saling memperkuat antar wilayah perdesaandi Kecamatan Wonosari Kabupaten Bondowoso, juga didasarkan atas prinsip strategi keterkaitan (linkages) antar potensi di setiap kawasan perdesaan. Hal ini dapat diwujudkan dengan mengembangkan karakteristik fisik kawasan perdesaan dengan membangun berbagai infrastruktur publik.

Pola pendekatan kebijakan yang bersifat spesifik merupakan strategi yang dapat mendorong terwujudnya perencanaan pembangunan perdesaaan yang berbasis pada potensi wilayah dengan memperhatikan faktor derajat kelompok perkembangan perdesaan. Pada tabel dibawah menjelaskan karakteristrik masing-masing derajat keragaaan perkembangan wilayah perdesaan di Kecamatan Wonosari Kabupaten Bondowoso serta arah pengembangan strategis dan terpadu terhadap perdesaan yang berbasis pada potensi wilayah.

Tabel 4

Formulasi Strategi terhadap Pengembangan Kawasan Perdesaan di Kecamatan Wonosari Kabupaten Bondowoso

\begin{tabular}{|c|c|c|}
\hline $\begin{array}{l}\text { Derajat Keragaan } \\
\text { Perdesaan }\end{array}$ & $\begin{array}{c}\text { Karakteristik Kawasan } \\
\text { Perdesaan }\end{array}$ & $\begin{array}{l}\text { Strategi Pengembangan Kawasan } \\
\text { Perdesaan di Kecamatan Wonosari }\end{array}$ \\
\hline \multirow{4}{*}{$\begin{array}{c}\text { Wilayah } \\
\text { perdesaan dengan } \\
\text { tingkat } \\
\text { perkembangan } \\
\text { baik } \\
\text { (Hierarkhi I) }\end{array}$} & 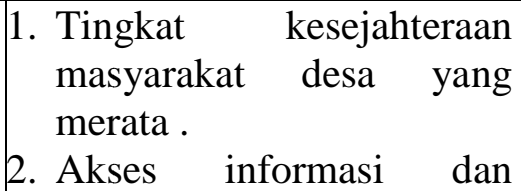 & $\begin{array}{l}\text { 1. Meningkatkan kualitas SDM salah } \\
\text { satunya melalui peningkatan akses } \\
\text { terhadap sarana teknologi } \\
\text { informasi }\end{array}$ \\
\hline & $\begin{array}{lr}\text { komunikasi baik dan } \\
\text { mendukung, aksesbilitas } \\
\text { terhadap } & \text { pusat } \\
\text { pemerintahan } & \text { kecamatan }\end{array}$ & $\begin{array}{l}\text { 2. Meningkatkan peran serta aktif } \\
\text { warga masyarakat pada kegiatan } \\
\text { ekonomi melalui lembaga-lembaga } \\
\text { keagamaan. }\end{array}$ \\
\hline & $\begin{array}{l}\text { 3. Daya dukung sarana } \\
\text { pendidikan dan kesehatan } \\
\text { yang memadai }\end{array}$ & $\begin{array}{l}\text { 3. Penguatan usaha rumahtangga dan } \\
\text { industri kecil/mikro dengan } \\
\text { meningkatkan daya saing produk }\end{array}$ \\
\hline & & $\begin{array}{l}\text { 4. Meningkatkan aksesbilitas } \\
\text { permodalan usaha, dan pemasaran. }\end{array}$ \\
\hline
\end{tabular}


Published December 2018

EKONOMIKAWAN : Jurnal IImu Ekonomi dan Studi Pembangunan

ISSN : 1693-7600 (Print), ISSN : 2598-0157 (Online), http://jurnal.umsu.ac.id/index.php/ekawan

\begin{tabular}{|c|c|c|}
\hline $\begin{array}{c}\text { Wilayah } \\
\text { perdesaan dengan } \\
\text { tingkat } \\
\text { perkembangan } \\
\text { sedang } \\
\text { (Hierarkhi II) }\end{array}$ & $\begin{array}{l}\text { 1. Tingkat kesejahteraan } \\
\text { penduduk tinggi, } \\
\text { 2. Akses informasi dan } \\
\text { komunikasi baik dan } \\
\text { mendukung, akses terhadap } \\
\text { pusat pemerintahan } \\
\text { kecamatan cukup baik, } \\
\text { 3. Jumlah dan akses sarana } \\
\text { pendidikan dan kesehatan } \\
\text { yang memadai, sarana } \\
\text { ekonomi memadai, kualitas } \\
\text { lingkungan baik, partisipasi } \\
\text { warga tinggi }\end{array}$ & $\begin{array}{l}\text { 1. Penguatan usaha rumah tangga } \\
\text { dan industri kecil/mikro dengan } \\
\text { meningkatkan daya saing } \\
\text { produk melalui diversifikasi } \\
\text { produk } \\
\text { 2. Meningkatan terhadap akses } \\
\text { permodalan usaha, dan } \\
\text { meningkatkan kualitas SDM } \\
\text { melalui peningkatan akses } \\
\text { terhadap sarana teknologi } \\
\text { informasi dan lembaga } \\
\text { kursus/keterampilan }\end{array}$ \\
\hline $\begin{array}{c}\text { Wilayah } \\
\text { perdesaan dengan } \\
\text { tingkat } \\
\text { perkembangan } \\
\text { kurang } \\
\text { (Hierarkhi III) }\end{array}$ & $\begin{array}{l}\text { 1. Tingkat kesejahteraan } \\
\text { penduduk rendah, akses } \\
\text { terhadap pusat pemerintahan } \\
\text { kecamatan rendah. } \\
\text { 2. Daya dukung sarana ekonomi } \\
\text { terbatas, kualitas lingkungan } \\
\text { rendah, partisipasi warga } \\
\text { rendah }\end{array}$ & 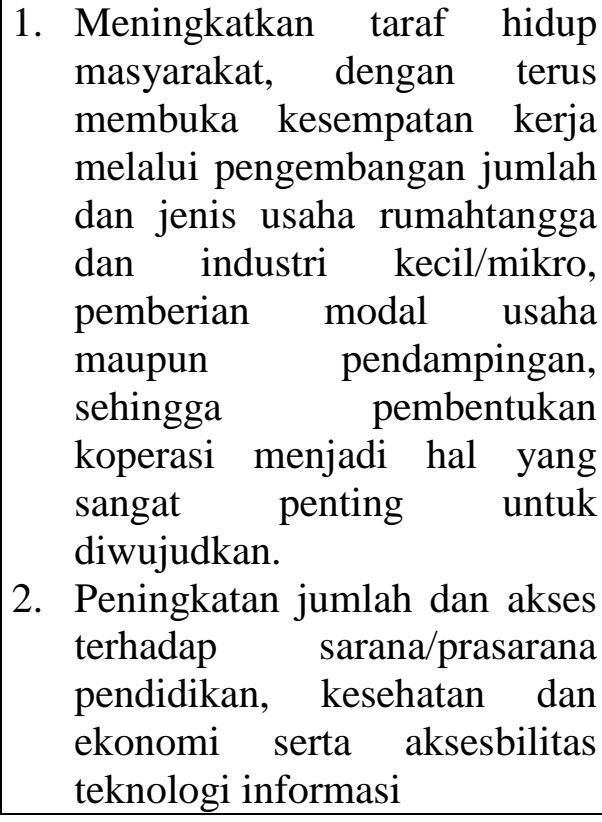 \\
\hline
\end{tabular}

\section{Wilayah Perdesaan Berbasis Potensi Agribis Kopi Rakyat di Kecamatan Sumberwringin Kabupaten Bondowoso}

Hasil analisis terhadap variabel keragaan perkembangan perdesaan salah satunya menghasilkan skor setiap desa. Tujuan dari analisis kelompok ini adalah untuk membuat pengelompokan (clustering) perkembangan desa di Kecamatan Sumberwringin Kabupaten Bondowoso yang mempunyai basis potensi wilayah ekonomi agribis kopi rakyat. Data perkembangan kawasan perdesaan di Kecamatan Sumberwringin Kabupaten Bondowoso terbagi menjadi 3 (tiga) kelompok yang dijelaskan pada tabel dibawah. 


\section{Published December 2018}

\section{EKONOMIKAWAN : Jurnal Ilmu Ekonomi dan Studi Pembangunan}

ISSN : 1693-7600 (Print), ISSN : 2598-0157 (Online), http://jurnal.umsu.ac.id/index.php/ekawan

Tabel 5

Kategori Perkembangan Desa di Kecamatan Sumberwringin

\begin{tabular}{|c|l|c|}
\hline No & \multicolumn{1}{|c|}{ Nama Desa } & Kategori Perkembangan Desa \\
\hline 1 & Sumbergading & Kelompok Hirarkhi ke I \\
\hline 2 & Sukorejo, Sukosarikidul & Kelompok Hirarkhi ke II \\
\hline 3 & Tegaljati, Rejoagung & Kelompok Hirarkhi ke III \\
\hline
\end{tabular}

Perkembangan kawasan desa di wilayah Kecamatan Sumberwringin Kabupaten Bondowoso akan lebih jelas apabila diilustrasikan dengan gambar berikut ini.

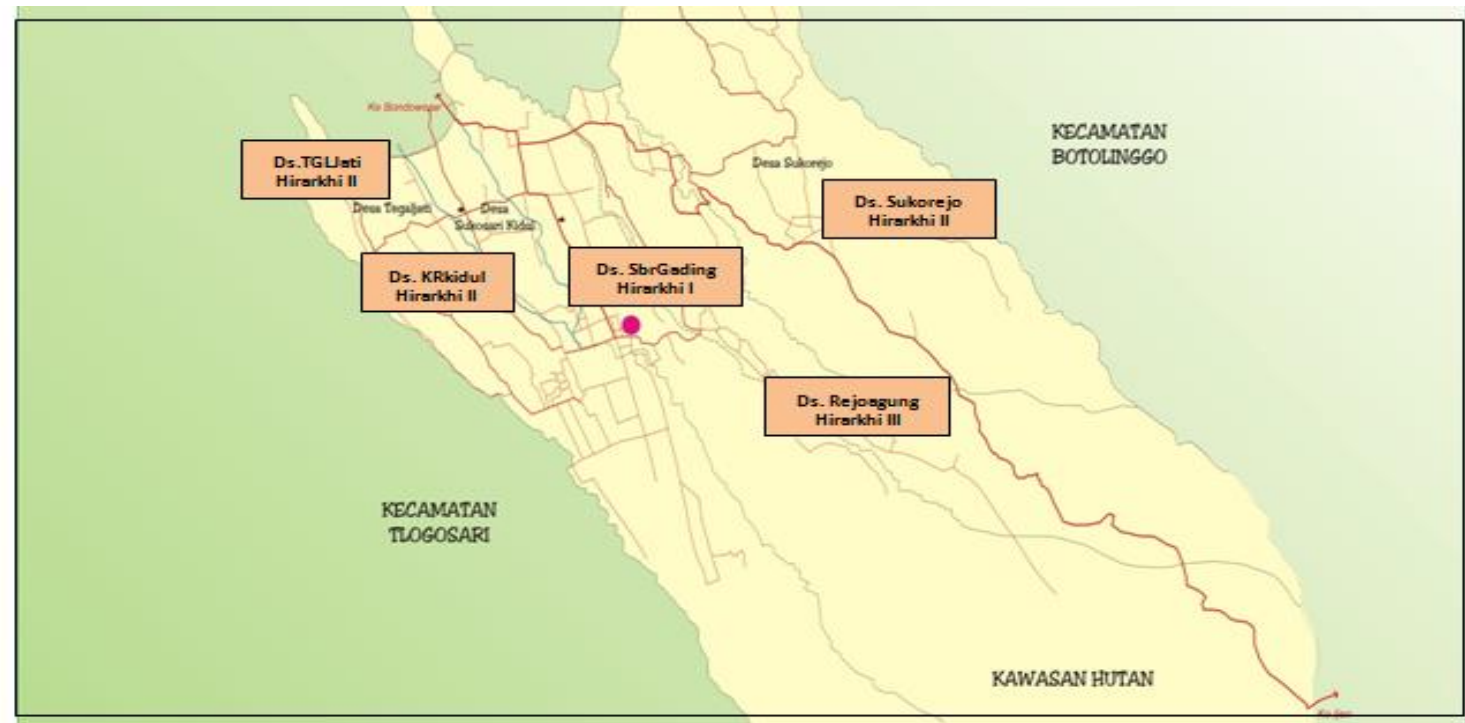

Gambar 3

Penyebaran Perkembangan Desa di Kecamatan Sumberwringin

Pola pendekatan kebijakan yang bersifat spesifik merupakan strategi yang dapat mendorong terwujudnya perencanaan pembangunan perdesaaan yang berbasis pada potensi wilayah dengan memperhatikan faktor derajat kelompok perkembangan perdesaan. Pada tabel dibawah menjelaskan karakteristrik masing-masing derajat keragaaan perkembangan wilayah perdesaan di Kecamatan Sumberwringin Kabupaten Bondowoso serta arah pengembangan strategis dan terpadu terhadap perdesaan yang berbasis pada potensi wilayah. 


\section{Published December 2018}

\section{EKONOMIKAWAN : Jurnal Ilmu Ekonomi dan Studi Pembangunan}

ISSN : 1693-7600 (Print), ISSN : 2598-0157 (Online), http://jurnal.umsu.ac.id/index.php/ekawan

Tabel 6

Formulasi Strategi Pengembangan Perdesaan di Kecamatan Sumberwringin

\begin{tabular}{|c|c|c|}
\hline $\begin{array}{l}\text { Derajat } \\
\text { Keragaan } \\
\text { Perdesaan }\end{array}$ & $\begin{array}{c}\text { Karakteristik Kawasan } \\
\text { Perdesaan }\end{array}$ & $\begin{array}{c}\text { Strategi Pengembangan Kawasan } \\
\text { Perdesaan di Kecamatan } \\
\text { Sumberwringin }\end{array}$ \\
\hline $\begin{array}{c}\text { Wilayah } \\
\text { perdesaan } \\
\text { dengan tingkat } \\
\text { perkembangan } \\
\text { baik } \\
\text { (Hierarkhi I) }\end{array}$ & $\begin{array}{l}\text { 1. } \text { Tingkat kesejahteraan } \\
\text { masyarakat desa yang } \\
\text { merata . informasi dan } \\
\text { 2. Akses baik dan } \\
\text { komunikasi bi akesbilitas } \\
\text { mendukung, pusat } \\
\text { terhadap arana } \\
\text { pemerintahan kecamatan } \\
\text { 3. Daya dukung sarana } \\
\text { pendidikan dan kesehatan } \\
\text { yang memadai } \\
\text { 4. Dayadukung } \\
\text { ekonomi memadai, kualitas } \\
\text { lingkungan baik. }\end{array}$ & $\begin{array}{l}\text { 1. Meningkatkan kualitas SDM salah } \\
\text { satunya melalui peningkatan akses } \\
\text { terhadap sarana teknologi informasi } \\
\text { 2. Meningkatkan peran serta aktif } \\
\text { warga masyarakat pada kegiatan } \\
\text { ekonomi melalui lembaga-lembaga } \\
\text { keagamaan. } \\
\text { 3. Penguatan usaha rumahtangga dan } \\
\text { industri kecil/mikro dengan } \\
\text { meningkatkan daya saing produk } \\
\text { 4. Meningkatkan aksesbilitas } \\
\text { permodalan usaha, dan pemasaran. } \\
\text { 5. Optimalisasi kelembagaan petani di } \\
\text { kawasan perdesaan }\end{array}$ \\
\hline $\begin{array}{l}\text { Wilayah } \\
\text { perdesaan } \\
\text { dengan tingkat } \\
\text { perkembangan } \\
\text { sedang } \\
\text { (Hierarkhi II) }\end{array}$ & $\begin{array}{l}\text { 1. Tingkat kesejahteraan } \\
\text { penduduk tinggi, } \\
\text { 2. Akses informasi dan } \\
\text { komunikasi baik dan } \\
\text { mendukung, akses terhadap } \\
\text { pusat pemerintahan } \\
\text { kecamatan cukup baik, } \\
\text { 3. Jumlah dan akses sarana } \\
\text { pendidikan dan kesehatan } \\
\text { yang memadai, sarana } \\
\text { ekonomi memadai, kualitas } \\
\text { lingkungan baik, partisipasi } \\
\text { warga tinggi }\end{array}$ & $\begin{array}{l}\text { 1. Penguatan usaha rumah tangga dan } \\
\text { industri kecil/mikro dengan } \\
\text { meningkatkan daya saing produk } \\
\text { melalui diversifikasi produk. } \\
\text { 2. Meningkatan terhadap akses } \\
\text { permodalan usaha, dan } \\
\text { meningkatkan kualitas SDM melalui } \\
\text { peningkatan akses terhadap sarana } \\
\text { teknologi informasi dan lembaga } \\
\text { kursus/keterampilan }\end{array}$ \\
\hline $\begin{array}{c}\text { Wilayah } \\
\text { perdesaan } \\
\text { dengan tingkat } \\
\text { perkembangan } \\
\text { kurang } \\
\text { (Hierarkhi III) }\end{array}$ & 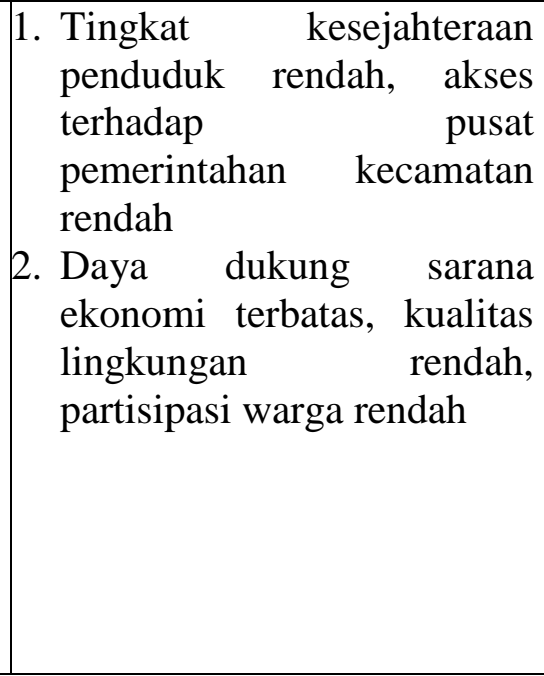 & $\begin{array}{l}\text { 1. Meningkatkan taraf hidup } \\
\text { masyarakat, dengan terus membuka } \\
\text { kesempatan kerja melalui } \\
\text { pengembangan jumlah dan jenis } \\
\text { usaha rumahtangga dan industri } \\
\text { kecil/mikro, pemberian modal usaha } \\
\text { maupun pendampingan, sehingga } \\
\text { pembentukan koperasi menjadi hal } \\
\text { yang sangat penting untuk } \\
\text { diwujudkan. } \\
\text { 2. Peningkatan jumlah dan akses } \\
\text { terhadap sarana/prasarana } \\
\text { pendidikan, kesehatan dan ekonomi } \\
\text { serta aksesbilitas teknologi informasi }\end{array}$ \\
\hline
\end{tabular}




\section{Published December 2018}

EKONOMIKAWAN : Jurnal Ilmu Ekonomi dan Studi Pembangunan

ISSN : 1693-7600 (Print), ISSN : 2598-0157 (Online), http://jurnal.umsu.ac.Id/index.php/ekawan

\section{Wilayah Perdesaan Berbasis Potensi Agroindustri Tape dan Ikan Air Tawar di Kecamatan Binakal Kabupaten Bondowoso}

Hasil analisis terhadap variabel keragaan perkembangan perdesaan salah satunya menghasilkan skor setiap desa. Tujuan dari analisis kelompok ini adalah untuk membuat pengelompokan (clustering) perkembangan desa di Kecamatan Binakal Kabupaten Bondowoso yang mempunyai basis potensi wilayah agroindustri tape dan ikan air tawar. Data perkembangan kawasan perdesaan di Kecamatan Binakal Kabupaten Bondowoso terbagi menjadi 3 (tiga) kelompok yang dijelaskan pada tabel dibawah.

Tabel 7

Kategori Perkembangan Desa di Kecamatan Binakal

\begin{tabular}{|c|l|c|}
\hline No & \multicolumn{1}{|c|}{ Nama Desa } & Kategori Perkembangan Desa \\
\hline 1 & Sumbertengah dan Bendelan & Kelompok Hirarkhi ke I \\
\hline 2 & Jeruk Soksok, Binakal, Baratan & Kelompok Hirarkhi ke II \\
\hline 3 & Gadingsari, Sumber Waru, Kembangan & Kelompok Hirarkhi ke III \\
\hline
\end{tabular}

Perkembangan kawasan desa di wilayah Kecamatan Binakal Kabupaten Bondowoso akan lebih jelas apabila diilustrasikan dengan gambar berikut ini.

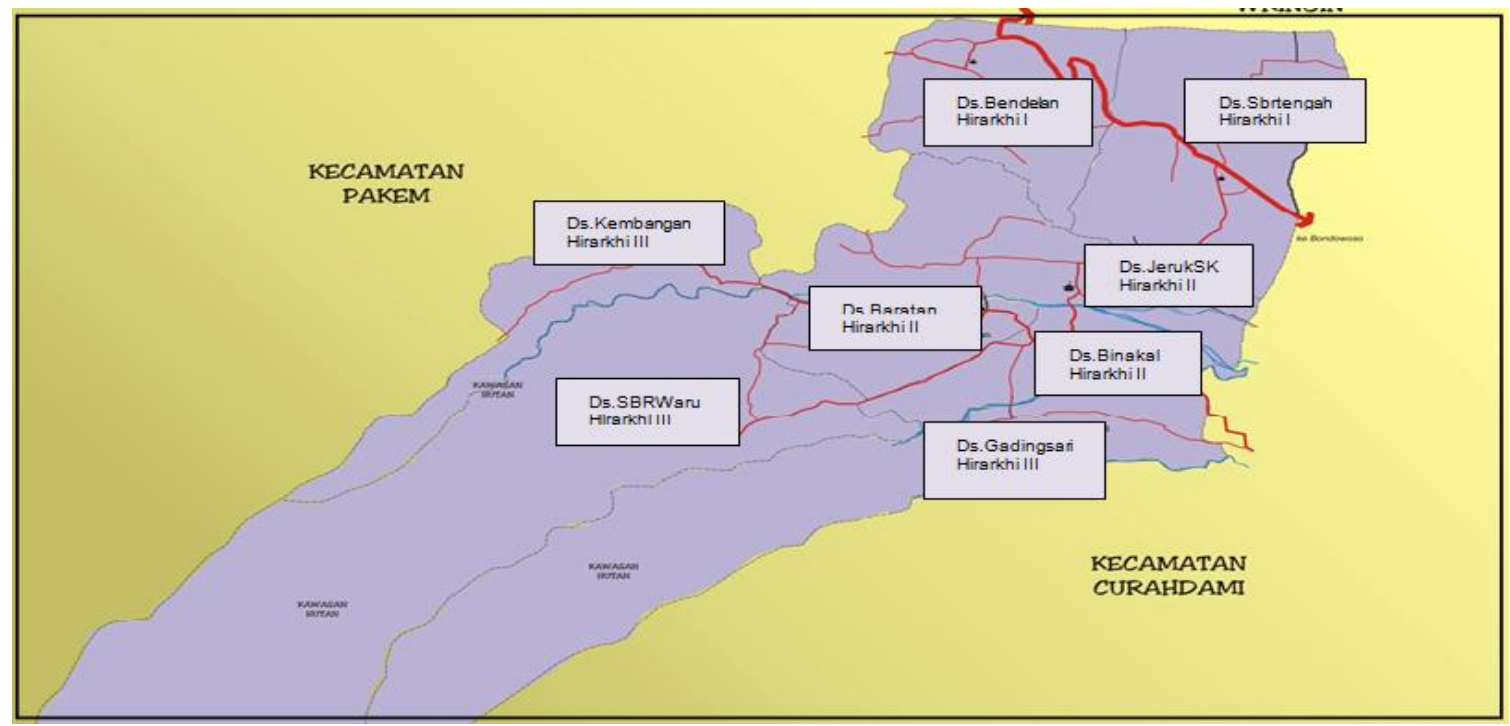

Gambar 4

Penyebaran Perkembangan Desa di Kecamatan Binakal

Pada tabel dibawah menjelaskan karakteristrik masing-masing derajat keragaaan perkembangan wilayah perdesaan di Kecamatan Binakal Kabupaten Bondowoso serta arah pengembangan strategis dan terpadu terhadap perdesaan yang berbasis pada potensi wilayah. 
Published December 2018

EKONOMIKAWAN : Jurnal Ilmu Ekonomi dan Studi Pembangunan

ISSN : 1693-7600 (Print), ISSN : 2598-0157 (Online), http://jurnal.umsu.ac.id/Index.php/ekawan

Tabel 8

Formulasi Strategi Pengembangan Kawasan Perdesaan di Kecamatan Binakal

\begin{tabular}{|c|c|c|}
\hline $\begin{array}{l}\text { Derajat Keragaan } \\
\text { Perdesaan }\end{array}$ & $\begin{array}{c}\text { Karakteristik Kawasan } \\
\text { Perdesaan }\end{array}$ & $\begin{array}{l}\text { Strategi Pengembangan Kawasan } \\
\text { Perdesaan di Kecamatan Binakal }\end{array}$ \\
\hline $\begin{array}{l}\text { Wilayah perdesaan } \\
\text { dengan tingkat } \\
\text { perkembangan baik }\end{array}$ & $\begin{array}{l}\text { 1. Tingkat kesejahteraan } \\
\text { penduduk tinggi. } \\
\text { 2. Akses informasi dan } \\
\text { komunikasi baik dan } \\
\text { mendukung, } \\
\text { 3. Aksesbilitas terhadap } \\
\text { pusat pemerintahan } \\
\text { kecamatan baik. } \\
\text { 4. Sarana pendidikan dan } \\
\text { kesehatan yang memadai, } \\
\text { 5. Sarana ekonomi cukup } \\
\text { memadai, kualitas } \\
\text { lingkungan baik,. }\end{array}$ & $\begin{array}{l}\text { 1. Meningkatan jumlah dan jenis } \\
\text { usaha rumah tangga dan industri } \\
\text { kecil/mikro. } \\
\text { 2. Meningkatkan jumlah dan akses } \\
\text { pada sarana pendidikan dan } \\
\text { kesehatan. } \\
\text { 3. Meningkatkan kualitas SDM } \\
\text { salah satunya melalui } \\
\text { peningkatan akses terhadap } \\
\text { sarana teknologi informasi dan } \\
\text { lembaga kursus/keterampilan } \\
\text { serta meningkatkan peran serta } \\
\text { aktif warga masyarakat melalui } \\
\text { lembaga-lembaga non profit }\end{array}$ \\
\hline $\begin{array}{l}\text { Wilayah perdesaan } \\
\text { dengan tingkat } \\
\text { perkembangan } \\
\text { sedang } \\
\quad \text { (Hierarkhi II) }\end{array}$ & $\begin{array}{l}\text { 1.Tingkat kesejahteraan } \\
\text { penduduk tinggi } \\
\text { 2. Akses informasi dan } \\
\text { komunikasi baik dan } \\
\text { mendukung, akses } \\
\text { terhadap pusat } \\
\text { pemerintahan kecamatan } \\
\text { 3. Akses sarana pendidikan } \\
\text { dan kesehatan yang } \\
\text { memadai. }\end{array}$ & $\begin{array}{l}\text { 1. Penguatan usaha rumah tangga } \\
\text { dan industri kecil/mikro dengan } \\
\text { meningkatkan daya saing produk. } \\
\text { 2. Meningkatkan kualitas SDM } \\
\text { melalui peningkatan akses } \\
\text { terhadap sarana teknologi } \\
\text { informasi dan } \\
\text { kursus/keterampilan }\end{array}$ \\
\hline $\begin{array}{l}\text { Wilayah perdesaan } \\
\text { dengan tingkat } \\
\text { perkembangan } \\
\text { kurang }\end{array}$ & $\begin{array}{l}\text { 1. Tingkat } \\
\text { kesejahteraan penduduk } \\
\text { rendah. } \\
\text { 2. Akses terhadap pusat } \\
\text { pemerintahan kecamatan } \\
\text { rendah. } \\
\text { 3. Sarana ekonomi } \\
\text { terbatas, } \\
\text { 4. Kualitas lingkungan } \\
\text { rendah,. } \\
\text { 5. Partisipasi warga } \\
\text { terhadap pembangunan } \\
\text { rendah }\end{array}$ & 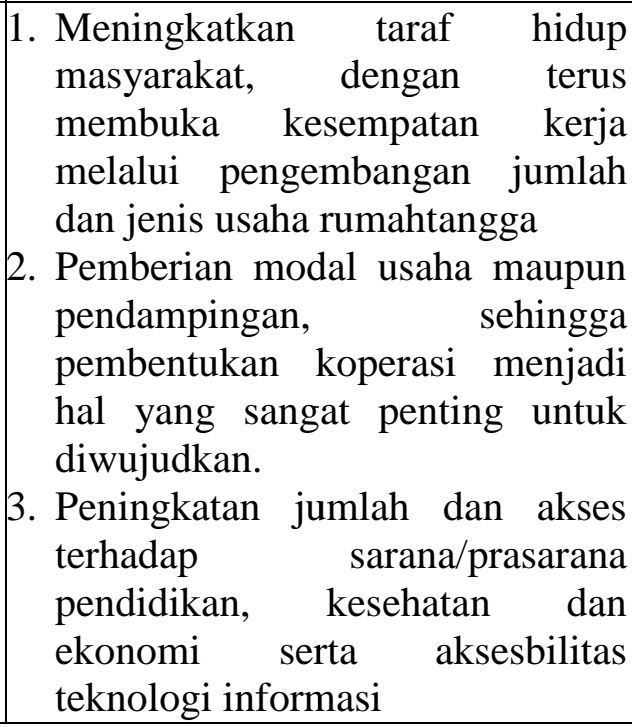 \\
\hline
\end{tabular}




\section{SIMPULAN}

Hasil penelitian yang telah dilakukan menyimpulkan diantaranya, yaitu : Kawasan perdesaan di wilayah Kabupaten Bondowoso mempunyai beberapa klasifikasi perkembangan desa yang menunjukan terdapat adanya kegiatan pembangunan yang belum merata di wilayah perdesaan, yaitu :

a. Keragaan relatif tingkat perkembangan desa di Kecamatan Tamanan dengan potensi ekonomi kreatif menghasilkan tiga hierarki, yaitu (1). Kelompok Hierarki I terdiri dari (Desa Tamanan, Desa Sukosari dan Desa Wonosuko), (2). Kelompok Hierarki II terdiri dari (Desa Karangmelok, Desa Kemirian, dan Desa Sumberkemuning) dan (3). Kelompok Hierarki III terdiri dari (Desa Mengen, Desa Sumberanom dan Desa Wonosuko).

b. Keragaan relatif tingkat perkembangan desa di Kecamatan Wonosari dengan potensi agribis padi organik menghasilkan tiga hierarki, yaitu (1). Kelompok Hierarki I terdiri dari (Desa Wonosari, Desa Traktakan dan Desa Sumberkalong), (2). Kelompok Hierarki II terdiri dari (Desa Kapuran, Desa Pasarejo, Desa Tumeng, Desa Lombok Kulon dan Desa Lombok Wetan) dan (3). Kelompok Hierarki III terdiri dari (Desa Tangsil Wetan, Desa Jumpong, Desa Pelalangan dan Desa Bendoarum).

c. Keragaan relatif tingkat perkembangan desa di Kecamatan Sumberwringin dengan potensi agribis kopi rakyat menghasilkan tiga hierarki, yaitu (1). Kelompok Hierarki I terdiri dari (Desa Sumbergading), (2). Kelompok Hierarki II terdiri dari (Desa Sukorejo dan Desa Sukosarikidul) dan (3). Kelompok Hierarki III terdiri dari (Desa Tegaljati dan Desa Rejoagung).

d. Keragaan relatif tingkat perkembangan desa di Kecamatan Binakal dengan potensi agroindustri tape dan ikan air tawar menghasilkan tiga hierarki, yaitu (1). Kelompok Hierarki I terdiri dari (Desa Sumbertengah dan Desa Bendelan), (2). Kelompok Hierarki II terdiri dari (Desa Jeruk Soksok, Desa Binakal dan Desa Baratan) dan (3). Kelompok Hierarki III terdiri dari (Desa Gadingsari, Desa Sumber Waru Desa Kembangan).

\section{DAFTAR PUSTAKA}

Anonim. 2012. Rural Economic Development Initiative (REDI). Division of Community Development Florida Department of Economic Opportunity. Florida.

Anwar, A. 2005. Ketimpangan Pembangunan Wilayah dan Perdesaan (Tinjauan Kritis). P4WPress. Bogor Rifai, S. A. 1989. Akuakultur dan Lingkungan. Makalah disajiakan dalam seminar Industri dan Lingkungan Hidup. Palemban 20-21 Juni 1989.Royce, W. F.2007.

Boeke, J.H. 1971. Batas-batas dari Masyarakat Pedesaan di Indonesia, LP3ES. Jakarta. . 1983. Prakapitalisme di Asia, Sinar Harapan. Jakarta.

Cohen, M., John. Uphoff, T., Norman. 1977. Rural Development Participation: Concepts and Measures for Project Design, Implementation and Evaluation. Ithaka. Cornel University

Collier, W.L., Santoso, K. 1996. A New Approach to Rural Development in Java: Twenty Five Years of Village Studies. Sajogyo (penerjemah). Pendekatan Baru Dalam Pembangunan Pedesaan di Jawa: Kajian Pedesaan Selama Dua Puluh Lima Tahun, Yayasan Obor Indonesia. Jakarta. 
Connell, D.J., Wall, E. 2004. New Rural Economy: Economic Capacity Profile. Journal of Extension. Volume : 42, Number : 4, http://www.joe.org/joe/2004august/a2.php. Agust 2017.

Dharmawan, A.H. 2006. Pendekatan-Pendekatan Pembangunan Pedesaan dan Pertanian: Klasik dan Kontemporer, makalah seminar "Apresiasi Perencanaan Pembangunan Pertanian Daerah bagi Tenaga Pemandu Teknologi Mendukung Prima Tani". Cisarua Bogor. 19-25 November.

Fakultas Ekonomi dan Bisnis Universitas Brawijaya. 2011. Spirit Konstitusi, Hegemoni Modal, dan Kedaulatan Ekonomi, Refleksi Akademik 50 Tahun Fakultas Ekonomi dan Bisnis Universitas Brawijaya. 8 Oktober.

Fukuyama, F. 2005. The Great Disruption: Human Nature and the Reconstitution of Social Order. Masri Maris (penerjemah). Guncangan Besar: Kodrat Manusia dan Tata Sosial Baru, Gramedia Pustaka Utama. Jakarta

Friedmann, John and Douglass. 1978. Agropolitan Development: Towards a New Strategy for Regional Planning in Asia.

Glasson, John. 1974. An Introduction to Regional Planning. Hutchinson Educational, London.

Gregg, S. 2010. Smith Versus Keynes: Economics and Political Economy in the Post-Crisis Era. Harvard Journal of Law \& Public Policy, Vol. 33, No. 2 Spring: 443-464.

Ismail, M. 2003. Sumbangan Institusi Lokal Dalam Pembangunan Ekonomi. dalam Iwan Triyuwono dan Ahmad Erani Yustika (eds.), Emansipasi Nilai Lokal: Ekonomi dan Bisnis Pascadesentralisasi Pembangunan, Bayumedia Publishing. Malang: 1-22.

Juliantara, D. 2003. Pembaruan Desa: Bertumpu pada yang Terbawah, Lappera Pustaka Utama. Yogyakarta.

Malik, A. 2008. Implementasi Perimbangan Keuangan Antara Kabupaten dan Desa Melalui Alokasi Dana Desa (ADD) Dalam Menunjang Pembangunan Desa: Studi Kasus Tiga Desa di Kabupaten Bondowoso. Disertasi, Program Pascasarjana Fakultas Ekonomi Universitas Brawijaya. Malang.

Maryunani (ed.). 2002. Alokasi Dana Desa: Formulasi dan Implementasi, LPEM Fakultas Ekonomi Universitas Brawijaya. Malang.

- 2007. Sentuhan Pembangunan Ekonomi Dalam Penguatan Perekonomian Desa di Indonesia, Pidato Pengukuhan Guru Besar dalam Bidang Ilmu Ekonomi Pembangunan, Fakultas Ekonomi Universitas Brawijaya. 22 Oktober.

Munawar. 2007. Kritik Sosiologis Terhadap Kedudukan Individu Dalam Bangunan Teori Ekonomi Neoklasik, Pidato Pengukuhan Guru Besar dalam Bidang Ilmu Ekonomi Makro, Fakultas Ekonomi Universitas Brawijaya. 10 Desember.

Naghavi, M. A. S., Salavati, A., and Movahed, E. S. B. 2011. Public Sector Success in Social Capital: A Comparative Study in Iran's Governmental and Private Banks, European Journal of Social Sciences, Vol. 24, No. 1: 33-41.

Osborne, D., Gaebler, T. 1996. Reinventing Government: How the Entrepreneurial Spirit is Transforming the Public Sector. Abdul Rosyid (penerjemah). Mewirausahakan Birokrasi: Mentransformasi Semangat Wirausaha ke dalam Sektor Publik, Pustaka Binaman Pressindo. Jakarta. 


\section{Published December 2018}

EKONOMIKAWAN : Jurnal Ilmu Ekonomi dan Studi Pembangunan

ISSN : 1693-7600 (Print), ISSN : 2598-0157 (Online), http://jurnal.umsu.ac.id/index.php/ekawan

Stiglitz, J.E. 2003. The Roaring Nineties: A New History of the World's Most Prosperous Decade. Aan Suhaeni (penerjemah). Dekade Keserakahan: Era '90-an dan Awal Mula Petaka Ekonomi Dunia, Marjin Kiri. Serpong-Tangerang.

Sumodiningrat, G. 2001. Responsi Pemerintah Terhadap Kesenjangan Ekonomi: Studi Empiris pada Kebijaksanaan dan Program Pembangunan dalam rangka Pemberdayaan Masyarakat di Indonesia, PerPod. Jakarta.

Wasistiono, S., Tahir, M.I. 2007. Prospek Pengembangan Desa, Fokusmedia. Bandung.

Woolcock, M., Narayan, D. 2000. Social Capital: Implications for Development Theory, Research, and Policy. The World Bank Research Observer, Vol. 15, No. 2: 225-249.

Wulandari, I.T. 2008. Peran Modal Sosial dalam Pengembangan Usaha Simpan Pinjam pada BUMDes: Studi Kasus BUMDes Desa Semambung Kec. Gedangan Kab. Sidoarjo. Tesis, Program Pascasarjana Fakultas Ekonomi Universitas Brawijaya. Malang.

Yuliati, Y., Poernomo, M. 2003. Sosiologi Pedesaan. Lappera Pustaka Utama. Yogyakarta. Yustika, A.E. 2003. Industrialisasi, Urbanisasi, dan Sektor Informal: Perspektif Kebijakan Lokal. dalam Iwan Triyuwono dan Ahmad Erani Yustika (eds.), Emansipasi Nilai Lokal: Ekonomi dan Bisnis Pascadesentralisasi Pembangunan, Bayumedia Publishing. Malang: 33-50.

2008. Ekonomi Kelembagaan: Definisi, Teori, dan Strategi, Bayumedia Publishing. Malang.

2009. Ekonomi Politik: Kajian Teoretis dan Analisis Empiris, Pustaka Pelajar. Yogyakarta. 